\title{
The Effect of Adjuvant Chemotherapy on Sexual Satisfaction and Quality of Life in Breast Cancer Patients and Their Partners Izmir Oncology Group (IZOG) Study
}

\section{Meme Kanserli Hastalarda ve Eşlerinde Adjuvan Kemoterapinin Seksüel Doyum ve Yaşama Kalitesi Üzerine Olan Etkileri-İzmir Onkloji Grubu (IZOG) Çalışması}

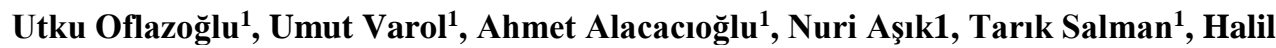 \\ Taşkaynatan $^{1}$, Yüksel Küçükzeybek ${ }^{1}$, Yaşar Yıldız ${ }^{1}$, Mustafa Oktay Tarhan² \\ ${ }^{1}$ Department Of Medical Oncology, Izmir Katip Celebi University Ataturk Training And Resarch Hospital, \\ Izmir, Turkey \\ ${ }^{2}$ Department Of Medical Oncology, Institute Of Oncology, Dokuzeylul University, Izmir, Turkey
}

Dergiye Ulaşma Tarihi:21.01.2018 Dergiye Kabul Tarihi:01.10.2018 Doi: 10.5505/aot.2018.29494

\section{ÖZET}

GİRIŞ ve AMAÇ: Meme kanseri tedavisi gören kadınların ameliyat ve kemoterapi ile sıklıkla cinsel işlev bozuklukları yaşadığını gösteren kanıtlar artmaktadır. Çalışmamızın bir parçası olarak, yaşam kalitesini (YK) ve cinsel doyum düzeylerini ve ayrıca kemoterapinin Türk meme kanseri hastalarının ve partnerlerinin cinsel doyum üzerindeki etkilerini araştırmayı amaçladık

YÖNTEM ve GEREÇLER: Otuz iki meme kanseri hastasından ve partnerlerinden elde edilen verileri topladık. Üç form kullandık: biri hastaların sosyodemografik özellikleri, EORTC-QoL-C30 ve Cinsel Tatmini GolombokRust Envanteri (GRISS) hakkında bilgi içeriyor

BULGULAR: Meme kanseri hastalarının GRISS'e göre tedavi öncesi ve tedavi sonrasi cinsel memnuniyetlerinin karşılaştırıldığında, sıklık, kaçınma, dokunma ve anorgazmi için istatistiksel olarak anlamlı alt ölçekler osaptanmıştır (sırasıyla p <0.0001, <0.0001, 0.007 ve 0.001). Buna karşılık, sadece siklık parametreleri partnerlerinde belirgin olarak yüksekti (p: 0.001). Ayrıca, duygusal işlevsellik, sosyal işlevsellik ve bilişsel işlevsellik açısından hastalarımızda istatistiksel olarak anlamlı farklılıklar bulduk (sırasıyla $\mathrm{p}=0.023$, 0.022 ve 0.035 ).

TARTIŞMA ve SONUÇ: Kemoterapinin genel yaşam kalitesi puanlarını düşürmeden cinsel doyum oranlarını düşürdüğünü bulduk. Hastaların yaşam kalitesini değerlendirirken, cinsel doyumlarının kötüleşebileceği ihtimaline dikkat edilmelidir. Tüm onkoloji uzmanları, uygun tavsiyeleri yapmanın yanı sıra hastalarıyla açık diyaloğu teşvik etmeleri için çok önemlidir; kemoterapinin zararlı etkilerini en aza indirgemek ve yaşam kalitesini iyileştirmek için antikanser tedavisi öncesi, sırasında ve sonrasında izlenmelidirler.

Anahtar Kelimeler: Yaşam kalitesi, cinsel doyum, meme kanseri, bilişsel fonksiyon, kemoterapi

ABSTRACT
INTRODUCTION: There is growing evidence suggesting that women treated for breast cancer with surgery
and chemotherapy commonly experience disturbances in sexual functioning. As part of the present study, we
aimed to investigate quality of life (QoL) and sexual satisfaction levels, as well as the effects of chemotherapy
upon the sexual satisfaction of Turkish breast cancer patients and their partners.
METHODS: We collected data were from thirty-two breast cancer patients and their partners. We used three
forms: one is covering information about socio-demographic characteristics of the patients, EORTC-QoL-C30
and the Golombok-Rust Inventory of Sexual Satisfaction (GRISS).
RESULTS: A comparison of the pre-treatment and post-treatment sexual satisfaction of breast cancer patients
with respect to GRISS showed statistically significant subscores of frequency, avoidance, touch and anorgasmia
(p: <0.0001, <0.0001, 0.007 and 0.001 respectively). In contrast, only the frequency parameter was significantly
high in their partners (p: 0.001). Also, we found statistically significant differences in our patients in terms of
emotional functioning, social functioning, and cognitive functioning (p: 0.023 , 0.022 and 0.035 , respectively).
DISCUSSION AND CONCLUSION: We found that chemotherapy reduced sexual satisfaction rates without
lowering overall quality of life scores. While assessing patients' quality of life, one should pay sufficient
attention to the possibility that their sexual satisfaction may get worse. It is of crucial importance for all the
oncology professionals to encourage open dialogue with their patients in addition to making appropriate

Adress for correspondence: Uzm. Dr. Utku Oflazoğlu İzmir Katip Çelebi Üniversitesi Atatürk Eğitim Ve Araştırma Hastanesi. Tıbbi Onkoloji Polkiniği Yeşilyurt/İzmir, Turkey 
referrals; and they should be monitored before, during, and after anticancer treatment to minimize the deleterious effects of chemotherapy and improve their quality of life.

Keywords: Quality of life, sexual satisfaction, breast cancer, cognitive functioning, chemotherapy.

\section{INTRODUCTION}

With an increasing incidence, breast cancer is the most common type of cancer among women, and it comprises $18 \%$ of all female cancers. (1,2) The adjuvant chemotherapy is commonly used because of this frequency and high resectability rate. Thanks to the adjuvant therapy modalities being developed, patients present increased survival rates and they are at the same time exposed to side effects associated with the treatment. Alongside the better-known ones, these side effects include the less-investigated ones such as the quality of life and sexual dysfunction.

Breast cancer is the cancer of an organ that symbolizes femininity and has been mostly investigated in terms of its aspects related to sexuality and intimacy. (3) In addition, the importance of quality of life (QoL) has become prominent in breast cancer survivors due to the increasing number of effective treatments. Therefore, physical and psychological aspects of QoL are important factors in survival and overall patient health. $(4,5)$

Breast cancer treatment creates a stressful situation, not only from the physical but also from the psychological point of view. There is growing evidence that women treated for breast cancer with surgery and chemotherapy commonly experience disturbances in sexual functioning. Recent studies have revealed that breast cancer and its treatment methods (chemotherapy or hormone therapy) have had a negative effect on the sexual life of breast cancer survivors. (6-9) The research shows that the reason for the sexual problems associated with breast cancer patients appears to be much more related to the chemotherapy treatment than the type of surgery. (10) The most common sexual disturbances experienced by these patients were decreased sexual desire and arousal, painful intercourse, and anorgasmia. (11,12) Sexuality includes a need for touch, desire for sexual activities, communication to a partner and the ability to engage in satisfying sexual activities. However, for many women, sexuality does not only signify the ability to have intercourse but also includes the phenomena of femininity, attractiveness, ideas of body image and motherhood. It can also encompass an emotional and intellectual connection and sociocultural relationship. (13)

Despite the increase in the number of studies examining the psychosocial factors in breast cancer patients, few studies have focused on the changes in both the cancer patients and their partners. Partners need psychosocial support during the treatment and examination period, as they take greater responsibility for their home and family. Partners of cancer survivors were found to have problems like fatigue, sleep disturbance, eating and mood disorders, relationship difficulties, sexual morbidity and work disruption. (14)

There are limited data available on the extent to which the adjuvant therapy (anthracycline plus taxane combination), which is utilized frequently in breast cancer, affects the patients' sexual status. No single study has so far been able to clarify how the chemotherapeutics with a high emetogenic potential and side effects such as neuropathy, fatigue and exhaustion affect the quality of life and sexual satisfaction. The aim of the present study was therefore to investigate the effect of adjuvant chemotherapy on the quality of life and sexual satisfaction of the Turkish breast cancer patients and their partners.

\section{Materials and methods}

\section{Data collection}

Thirty-two premenopausal and sexually active breast cancer patients, who received adjuvant chemotherapy in Medical Oncology Clinics of Izmir Katip Celebi University Ataturk Research and Training Hospital between May 2015 and September 2016, and their partners, were enrolled in this study. The data were collected using a series of forms covering information about the sexual satisfaction and QoL of the breast cancer patients and their husbands, which were completed by a psychologist of the clinic during face-to-face 
interviews. Out of 44 patients, twelve were excluded from the study, since ten patients and two partners refused to complete the questionnaire. Patients with any comorbidity and history of any chronic drug use were excluded from the analysis. Therefore, the data were analyzed based on a total of 32 patients and their partners. The participants were informed of the study and they provided oral and written consents.

The first form contained questions about the socio-demographic characteristics of the patients. The second form was the"European Organization for Research on Treatment of Cancer Questionnaires Quality of Life-C30" (EORTC-QoL-C30). It included 30 items measuring the QoL of cancer patients into three major domains: functional scales, global health/QoL and symptom scales. (15) The quality of life scale consists of two items and there are nine symptom scales associated with fatigue (three items), nausea and vomiting (two items), pain (two items), dyspnea, insomnia, loss of appetite, diarrhea, financial and constipation (one item each). Functional scales consist of physical (five items), social (two items), emotional (four items), role (two items) and cognitive (two items) items. (16)

The third form was the GolombokRust Inventory of Sexual Satisfaction (GRISS). The GRISS consists of a 28 -item questionnaire used to evaluate the presence and extent of sexual morbidity. It has two different versions intended for males and females. The GRISS features 12 subscales evaluating impotence, premature ejaculation, orgasmic disorder, vaginismus, lack of communication, avoidance in males and females, non-sensuality, insensitivity in males and females and dissatisfaction in males and females. A score of five points or higher in any category indicates sexual dysfunction. (17) In the present study, we used the female versions of GRISS for breast cancer patients and male versions for their partners. Five subscales (touch, satisfaction, avoidance, communication, and frequency) are common in both versions. We compared these five subscales. The other two subscales (vaginismus and anorgasmia in females; impotence and premature ejaculation in males) were not compared. A validation and reliability study of The Golombok-Rust Inventory in
Turkish population was conducted by Tuğrul et al. (18).

In the present study, we administered both EORTC-QoL-C30 and GRISS forms to our patients and their partners at the beginning of the treatment and after the end of it in order to compare the difference in the quality of life and sexual satisfaction of this cohort owing to an adverse effect of chemotherapy.

Statistical analysis:

All data were analyzed using SPSS for Windows version 20.0. Descriptive statistics summarized frequencies and percentages for categorical variables, the mean and standard deviation for continuous variables. For independent samples, T-tests were used to compare categorical variables. A value of $p<0.05$ was considered to indicate significance.

\section{RESULTS}

The mean age of breast cancer patients and their partners were $42.7 \pm 6.4$ (range:35-48) and 46.6 \pm 8.3 (range:42-57), respectively. About $45 \%$ of the patients and $55 \%$ of the partners were university graduates. Nearly half of the patients $(55 \%)$ and their husbands (45\%) received primary education. $40 \%$ of the patients underwent a total mastectomy. All patients received four cycles of doxorubicin plus cyclophosphamide (every 21 days) and then a weekly paclitaxel therapy for a period of 12 weeks.

A comparison of the pre-treatment and post-treatment sexual status of breast cancer patients with respect to GRISS revealed significantly high levels of the frequency, avoidance, touch and anorgasmia subscores among the patients (p: $<0.0001,<0.0001$, 0.007 , and 0.001 , respectively). When we compared the pre-treatment and post-treatment GRISS subscores of their partners, we found statistically significant high levels of the frequency (p: 0.001). The GRISS scores of patients and partners are shown in Table 1.

On the other hand, we analyzed the quality of life for only breast cancer patients in pre- and post-treatment periods, and we found statistically significant differences in emotional functioning, social functioning, and cognitive functioning ( $\mathrm{p}$ : $0.022,0.023$, and 0.035 , respectively). The comparison of pre-treatment and post-treatment EORTC-QoL-C30 scores of the patients is shown in Table 2. 
Table 1. Comparison of pre-treatment and posttreatment EORTC-QoL-C30 scores of the patients

\begin{tabular}{|c|c|c|c|}
\hline QoL & $\begin{array}{l}\text { Pre- } \\
\text { treatment(n } \\
: 32) \\
\text { Mean } \pm \text { SD }\end{array}$ & $\begin{array}{l}\text { Post- } \\
\text { treatment(n } \\
: 32) \\
\text { Mean } \pm \text { SD }\end{array}$ & $\begin{array}{l}P \\
\text { val } \\
\text { ue }\end{array}$ \\
\hline \multicolumn{4}{|l|}{ Functional Scale } \\
\hline $\begin{array}{l}\text { Physical } \\
\text { functioning }\end{array}$ & $80.1 \pm 14.4$ & $82.0 \pm 11.0$ & $\begin{array}{l}0.42 \\
7\end{array}$ \\
\hline Role functioning & $84.0 \pm 21.2$ & $84.0 \pm 15.3$ & 0.99 \\
\hline $\begin{array}{l}\text { Emotional } \\
\text { functioning }\end{array}$ & $72.4 \pm 22.7$ & $78.4 \pm 18.3$ & $\begin{array}{l}0.02 \\
3\end{array}$ \\
\hline $\begin{array}{l}\text { Social } \\
\text { functioning }\end{array}$ & $71.6 \pm 22.05$ & $66.0 \pm 18.3$ & $\begin{array}{l}0.02 \\
2\end{array}$ \\
\hline $\begin{array}{l}\text { Cognitive } \\
\text { functioning }\end{array}$ & $84.5 \pm 17.3$ & $77.4 \pm 17.8$ & $\begin{array}{l}0.03 \\
5\end{array}$ \\
\hline Symptom Scale & & & \\
\hline $\begin{array}{l}\text { Nausea and } \\
\text { vomiting }\end{array}$ & $11.7 \pm 17.0$ & $22.3 \pm 16.1$ & $\begin{array}{l}0.01 \\
3\end{array}$ \\
\hline Fatigue & $34.0 \pm 21.8$ & $34.0 \pm 17.3$ & 0.99 \\
\hline Pain & $26.5 \pm 19.3$ & $18.7 \pm 17.3$ & $\begin{array}{l}0.03 \\
7\end{array}$ \\
\hline Dyspnea & $10.4 \pm 17.8$ & $8.3 \pm 18.9$ & $\begin{array}{l}0.53 \\
6\end{array}$ \\
\hline Insomnia & $24.9 \pm 25.3$ & $23.9 \pm 17.8$ & 0.57 \\
\hline Appetite loss & $20.8 \pm 23.5$ & $24.9 \pm 16.9$ & 0.35 \\
\hline Constipation & $10.4 \pm 17.8$ & $6.2 \pm 13.1$ & 0.16 \\
\hline Diarrhea & $10.4 \pm 17.8$ & $20.8 \pm 21.9$ & $\begin{array}{l}0.00 \\
5\end{array}$ \\
\hline $\begin{array}{l}\text { Financial } \\
\text { problems }\end{array}$ & $28.1 \pm 32.9$ & $32.2 \pm 36.3$ & 0.35 \\
\hline $\begin{array}{l}\text { Global quality of } \\
\text { life }\end{array}$ & $66.9 \pm 20.6$ & $67.4 \pm 12.7$ & 0.85 \\
\hline
\end{tabular}

EORTC-QLQ-C30, European Organization for Research on Treatment of Cancer Questionnaires Quality of LifeC30. The bold values are statistically significant.

\section{DISCUSSION}

Cancer surgery and chemotherapy have the potential to make along-lasting impact on body image and self-respect. Social roles of the cancer patients may also be affected throughout the cancer treatment. In addition to breast cancer treatments, the traumatic nature of the cancer experience may also bring about sexual difficulties. These sexual difficulties especially appear to be commonly observed in breast cancer patients experiencing body image disturbances. (19)
Table 2. Comparison of pre-treatment and posttreatment GRISS scores of the patients and their partners

\begin{tabular}{|c|c|c|c|}
\hline GRISS & $\begin{array}{l}\text { Pre- } \\
\text { treatment(n } \\
: 32) \\
\text { Mean } \pm \text { SD }\end{array}$ & $\begin{array}{l}\text { Post- } \\
\text { treatment(n } \\
: 32) \\
\text { Mean } \pm \text { SD }\end{array}$ & $\begin{array}{l}\mathbf{P} \\
\text { valu } \\
\mathbf{e}\end{array}$ \\
\hline \multicolumn{4}{|l|}{ Patients } \\
\hline Frequency & $4.96 \pm 1.46$ & $6.18 \pm 1.78$ & $\begin{array}{l}<0.0 \\
01\end{array}$ \\
\hline Communication & $5.71 \pm 2.64$ & $6.00 \pm 2.25$ & 0.14 \\
\hline Satisfaction & $3.46 \pm 1.96$ & $3.68 \pm 1.83$ & 0.37 \\
\hline Avoidance & $4.21 \pm 2.22$ & $5.80 \pm 1.88$ & $\begin{array}{l}<0.0 \\
01\end{array}$ \\
\hline Touch & $4.87 \pm 2.44$ & $5.56 \pm 2.07$ & $\begin{array}{l}\mathbf{0 . 0 0} \\
7\end{array}$ \\
\hline Vaginismus & $4.87 \pm 1.58$ & $5.34 \pm 1.51$ & 0.08 \\
\hline Anorgasmia & $3.37 \pm 1.47$ & $3.87 \pm 1.53$ & $\begin{array}{l}0.00 \\
1\end{array}$ \\
\hline GRISS total & $1.46 \pm 0.50$ & $1.62 \pm 0.49$ & $\begin{array}{l}0.00 \\
2\end{array}$ \\
\hline \multicolumn{4}{|l|}{ Partners } \\
\hline Frequency & $4.43 \pm 1.24$ & $5.62 \pm 1.58$ & $\begin{array}{l}0.00 \\
1\end{array}$ \\
\hline Communication & $5.28 \pm 2.45$ & $4.90 \pm 2.46$ & 0.07 \\
\hline Satisfaction & $2.96 \pm 1.44$ & $3.28 \pm 1.37$ & 0.25 \\
\hline Avoidance & $1.90 \pm 1.72$ & $1.78 \pm 1.40$ & 0.63 \\
\hline Touch & $3.71 \pm 2.09$ & $3.53 \pm 2.10$ & 0.53 \\
\hline $\begin{array}{l}\text { Premature } \\
\text { Ejaculation }\end{array}$ & $6.21 \pm 1.31$ & $6.09 \pm 1.27$ & 0.45 \\
\hline $\begin{array}{l}\text { Erectile } \\
\text { dysfunction }\end{array}$ & $4.12 \pm 1.69$ & $4.09 \pm 1.57$ & 0.32 \\
\hline GRISS total & $1.71 \pm 0.45$ & $1.78 \pm 0.42$ & 0.32 \\
\hline
\end{tabular}

Given the fact that the sexual dysfunction is a common problem among breast cancer survivors who had received chemotherapy, women should be properly informed at an early stage of treatment. (6) Much of the studies conducted so far have investigated the long-term effects of chemotherapy in terms of sexual dysfunction. However, the present study examined, in a cross-sectional manner, the effect of a specific chemotherapy protocol on the patients' quality of life and sexual satisfaction both at the beginning and end of the treatment. When we compared pretreatment and post-treatment sexual satisfaction, we found statistical significance levels for the frequency, avoidance, touch and 
anorgasmia subscores among patients, and we determined statistical significance levels for the frequency of their partners.

In a study conducted by Alicikus et al., forty-one percent of sexually active breast cancer patients had experienced a deterioration of sexual functioning after treatment. This sexual dysfunction was found to be mainly due to loss of libido (80\%), loss of interest in the partner (54\%), and sexual dissatisfaction (59\%). Sexual problems tended to develop in the early course of treatment. (20) Another study further showed that the adjuvant chemotherapy (FEC plus docetaxel) in young breast cancer patients had a strong negative impact on different QoL domains; especially on menopausal symptoms, sexuality and body weight.

Malinovszky et al. treated sexually active breast cancer patients at baseline with either high-dose or conventional chemotherapy and compared the groups of patients with respect to their post-treatment sexual activity. The changes from baseline were not significantly different between the changes at 6 months or 12 months in the patients treated with conventional-dose chemotherapy. (21) In contrast, Joly et al. did not find any difference in the sexual functioning of breast cancer survivors (as measured by EORTC-QoL-C30) after chemotherapy treatment. (22) After an average period of 10 years, patients included in this study were randomized in a trial comparing cyclophosphamide, methotrexate, and fluorouracil (CMF) to no adjuvant chemotherapy. They found and concluded that the negative effects of chemotherapy on sexual satisfaction may diminish over time.

In the present study, we found that standard chemotherapy regimens negatively affected the cognitive, emotional and social functioning of breast cancer patients. However, conflicting data were reported in the literature on cognitive dysfunction in women undergoing adjuvant chemotherapy for breast cancer. This difference in the cognitive functioning scores of cancer patients may be due to the utilization of different chemotherapeutics as part of those studies. While some recent studies indicated a cognitive impairment in 15-50\% of adult solid tumor survivors who had received chemotherapy, Nicoletta et al. demonstrated that chemotherapy did not influence cognitive functions. $(23,24)$ The reason for the occurrence of cognitive dysfunction after chemotherapy remains unknown. There may be different mechanisms involved, such as direct toxic injury to neurons, DNA damage, oxidative stress, menopausal status, cytokine release, and arterial or venous thrombosis in central nervous system. A study conducted by Lôbo et al. on women with breast cancer who received chemotherapy reported a significant decrease in physical, social and cognitive functioning between the beginning and end of treatment (six complete cycles of chemotherapy). (25) On the other hand, in another study, women in all treatment groups reported good emotional functioning but decreased physical functioning at the end of primary treatment for breast cancer, which was the case particularly among women who had a mastectomy or received chemotherapy (26).

The reduced sexual satisfaction scores found part of the present study were considered to be associated with the deteriorated emotional, cognitive and social functions of the patients, which refer to the quality of life scores. One should also take into account the possibility that the process associated with direct effects of chemotherapy may also play a role in this regard.

Breast cancer is a phenomenon that may have psychosocial and psychosexual effects on both patients and their partners. Although there are many studies on the sexuality and quality of life of breast cancer patients in the literature, they rather focus on a single aspect of the breast cancer. The present study includes all the treatment-related quality of life parameters including sexual satisfaction as well. However, the limited number of cases included in the present study constitutes a major limitation; and the study continues given the consideration that it will be more appropriate to evaluate the long-term findings of the study in order to reveal the long-term effects of chemotherapy on sexual satisfaction.

All these data support the need for an evaluation and management of sexual difficulties in breast cancer survivors, particularly if the patients receive treatments with a potential to alter sexual functioning. Therefore, sexual morbidity should be a regular part of the clinical care of those female breast cancer patients treated with chemotherapeutics. 
Conflict of interest: The authors declare that they have no conflict of interest

\section{REFERENCES}

1. Cetin I, Topcul. M triple negative breast cancer: Asian Pac J Cancer Prev, 2014; 15, 2427-31

2. Alteri R, Bandi P, Brinton L, et al (2011). Breast Cancer Facts \& Figures, American Cancer Society, Atlanta, Georgia.

3. Hassan I, Cima RR. Quality of life after rectal resection and multimodality therapy: J SurgOncol 2007; 96:684-92.

4. De Aguiar SS, Bergmann A, Mattos IE. Quality of life as a predictor of overall survival after breast cancer treatment: Qual Life Res 2014; 23:627-37.

5. $\mathrm{Li} \mathrm{TC}, \mathrm{Li} \mathrm{CI}$, Tseng $\mathrm{CH}$, et al. Lin CC. et al. Quality of life predicts survival in patients with non-small cell lung cancer: BMC Public Health 2012; $12: 790$.

6. Ganz PA, Rowland JH, Desmond K, Meyerowitz BE, Wyatt GE. Life after breast cancer. Understanding women's health-related quality of life and sexual functioning: J ClinOncol1998; 16:501-14.

7. Meyerowitz BE, Sparks FC, Spears IK. Adjuvant chemotherapy for breast carcinoma: psychosocial implications: Cancer 1979; 43:1613-18.

8. Anllo LM. Sexual life after breast cancer: J Sex Marital Ther2000;26:241-48.

9. Berglund G, Nystedt M, Bolund C, et al. Effect of endocrine treatment on sexuality in premenopausal breast cancer patients: a prospective randomized study: J ClinOncol2001; 19:2788-96.

10. Ganz PA, Desmond KA, Leedham B, et al. Quality of life in longterm, disease-free survivors of breast cancer: a follow-up study: J Natl Cancer Inst 2002; 94:39-49.

11. Young-McCaughan S. Sexual functioning in women with breast cancer after treatment with adjuvant therapy: Cancer Nurs 1996; 19:308-19.

12. Rogers M, Kristjanson LJ. The impact on sexual functioning of chemotherapy-induced menopause in women: Cancer Nurs2002; 25:57-65.

13. Akyolcu N. Meme kanserinde cerrahi girişim sonrasi cinsel yasam. Meme Sagligi Dergisi, 2008; $4,77-83$.

14. Hodgkinson $K$, Butow $P$, Hunt GE, et al. Life after cancer: couples and partners psychological adjustment and supportive care needs. Support Care Cancer, 2007; 15, 405-15.

15. Aaronson NK, Ahmedzai S, Bergman B, et al. The European Organization for Research and Treatment of Cancer QLQ-c30: a quality of life instrument for use in international clinical trials in oncology: $\mathrm{J}$ Natl CancerInst 1993; 85:365-76.
16. Fayers $\mathrm{P}$, Aaronson $\mathrm{N}$, Bjordal $\mathrm{K}$, et al. The EORTC QLQ-C30 Scoring Manual, 3rd ed. Brussels: European Organisation for Research and Treatment of Cancer; 2001.

17. Rust J, Golombok S. The GRISS: a psychometric instrument for the assessment of sexual dysfunction: Arch Sex Behav 1986; 15:157-65.

18. Tuğrul C, Öztan N, Kabakçı E. Golombok-Rust Cinsel Doyum Ölçeği'nin standardizasyon çalısması: TürkPsikiyatriDergisi 1993; 4:83-8

19. Boquiren VM, Esplen MJ, Wong J, et al. Sexual functioning in breast cancer survivors experiencing body image disturbance: Psychooncology. 2016; Jan;25(1):66-76.

20. Alicikus ZA, Gorken IB, Sen RC, et al. Psychosexual and body image aspects of quality of life in Turkish breast cancer patients; a comparison of breast conserving treatment and mastectomy: Tumori. 2009; 95(2): 212-8.

21. KM Malinovszky, A Gould, E Foster, et al, on behalf of the Anglo Celtic Co-operative Oncology Group. Quality of life and sexual function after high-dose or conventional chemotherapy for highrisk breast cancer: British Journal of Cancer 2006; 95(12), $1626-1631$

22. Joly F, Espié M, Marty M, J-F Héron, and M Henry-Amar. Long-term quality of life in premenopausal women with node-negative localized breast cancer treated with or without adjuvant chemotherapy: Br J Cancer. 2000; 83:577582.

23. De Jong N, Candel MJ, Schouten HC, Abu-Saad $\mathrm{HH}$, Courtens AM. Prevalence and course of fatigue in breast cancer patients receiving adjuvant chemotherapy: Ann Oncol 2004; 15:896-905.

24. Nicoletta Biglia, Giulia Moggio, Elisa Peano, et al. Effects of Surgical and Adjuvant Therapies for Breast Cancer on Sexuality, Cognitive Functions, and Body Weightjsm: J Sex Med 2010; 7:18911900.

25. Lôbo AS, Fernandes AFC, Almeida PC, Carvalho CML, Sawada NO. Quality of life in women with breast cancer undergoing chemotherapy. Acta Paul Enferm 2014; 27(6):554-9

26. Ganz PA, Kwan L, Stanton AL, et al. Quality of life at the end of primary treatment of breast cancer: First results from the moving beyond cancer randomized trial. J Natl Cancer Inst 2004; 96: 376387. 